\title{
Psycholinguistic Features of Representation of Emotions by the Concept of «Fear»
}

\section{Психолінгвістичні особливості репрезентації емоцій за допомогою концепту «страх»}

\section{Nataliia Mykhalchuk}

Dr. in Psychology, Professor, Rivne State University of the Humanities, Rivne (Ukraine)

Scopus Author ID: 57214227898

ORCID ID: https://orcid.org/0000-0003-0492-9450

Researcher ID: A-9440-2019

E-mail: natasha1273@ukr.net

\section{Наталія Михальчук}

Доктор психологічних наук, професор, Рівненський державний гуманітарний університет, м. Рівне (Україна)

\section{Liana Onufriieva}

Ph. D. in Psychology, Assistant Professor, Professor of the Department, Head of the Department of General and Applied Psychology, Kamianets-Podilskyi National Ivan Ohiienko University, Kamianets-Podilskyi (Ukraine)

Scopus Author ID: 57214601047

ORCID ID: https://orcid.org/0000-0003-2442-4601

Researcher ID: R-5598-2018

E-mail: kpnu_lab_ps@ukr.net

\section{Ліана Онуфрієва}

Кандидат психологічних наук, доцент, професор кафедри, завідувач кафедри загальної та практичної психології, Кам'янець-Подільський національний університет імені Івана Огієнка, м. Кам'янець-Подільський (Україна)

Address for correspondence, e-mail: kpnu_lab_ps@ukr.net Copyright: (C) Mykhalchuk Nataliia, Onufriieva Liana

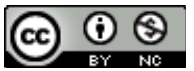
The article is licensed under CC BY-NC 4.0 International (https://creativecommons.org/licenses/by-nc/4.0/)

(C) Mykhalchuk Nataliia, Onufriieva Liana

DOI (article): https://doi.org/10.32626/2227-6246.2020-48.206-227 
The author's contribution: N. Mykhalchuk - 50\%, L. Onufriieva - 50\%. Авторський внесок: Н. Михальчук - 50\%, Л. Онуфрієва - 50\%.

\section{ABSTRACT}

The purpose of this article is to define the role of the concept of emotions in the conceptual and linguistic pictures of the world of Ukrainian and English people.

Methods of the research. The following theoretical methods of the research were used to solve the tasks formulated in the article: a categorical method, structural and functional methods, the methods of the analysis, systematization, modeling, generalization.

The results of the research. We think that fear is one of the fundamental emotions that performs a protective function and is accompanied by certain changes in the activity of higher nervous system, such as: changes in pulse rate and respiration, blood pressure indicators, function of stomach. However, it should be noted that feelings of fear stimulate the ability to respond to adverse factors of objective reality. Being at the highest point of emotional excitement, one seeks ways to solve the problem, because fear specifically distorts reality, imprinting on the nature of its perception and interpretation. In the unfavorable situation, a person seeks to get rid of the state of helplessness and intimidation as soon as it is possible to minimize the effect of threatening factor. We can conclude that ideas about the emotion "fear" are localized in the negative associative-shaped zone of the linguistic picture of the world.

Organizationally emotion-conceptosphere is a set of hierarchically ordered paradigm, verbalized using lexical and phraseological means of emotional concepts, which are "quanta", such as structured knowledge about the emotional life of the person, which are for each other in a complex of structuralsemantic and functional relationships. Therefore, for the research of the nature of the emotional-conceptual sphere, it is extremely important to understand the essence of the emotional concept, to describe and reflect their components, to analyze the linguistic means by which they are represented. Such a description needs to take into account the existing in the socio-cultural life of the community of psychological, sociological and semiotic factors, which together form a cultural factor that determines the formation and functioning of concepts as a cognitive-cultural phenomena.

Conclusions. Consequently, in contemporary English categorically different aspects of lexical unit of fear are fixed by derivative word-building units, which

(C) Mykhalchuk Nataliia, Onufriieva Liana DOI (article): https://doi.org/10.32626/2227-6246.2020-48.206-227 
explicate: the state of the person; features of the character of the person; negative evaluation of the object of the threat; manner of the behavior.

The frame of the emotional concept of fear, which contains data of a declarative nature, reflects the constant and unchanging features of the situation of the occurrence of fear: the appearance of threat causes the appearance of fear, which is presented in the physiological and behavioral reactions of a man.

Summarizing all the information, we consider the emotional concept of fear as a complex nuclear-peripheral configuration of knowledge about prototypical and not prototypical concepts, figurative and value attributes of the emergence, experience and elimination of emotion of fear. This configuration forms the conceptual basis on which the core of the meaning of the multilevel units of the given emotional concept in contemporary English is constructed. It is also participated in the formation of mental spaces that are constructed during the perception of fragments of English-language texts that describe the situation of the hero's experience of the state of fear. If the informative structure of the emotional concept is "responsible» for the denotative aspect of the meaning of its nominees, then their connotative aspect captures the concept's place in the English conceptual picture of the world. The status of the emotional concept of fear in it is conditioned by the attitude of the ethnos to the correlative emotion. The point is that, having a biological basis, fear receives a socialized, nationally and culturally conditioned form of the expression that is entirely based on a nationally specific, evaluative attitude of the person to emotions as a socialized phenomenon. Being the basis of the emotional concept of fear, this emotion projects the peculiarities of his / her experience on his / her semantic structure. In such a way the socialization of fear, which is largely normatively determined, predicts the status of the emotional concept under study as being essentially axiological, demonstrating the connection of its meaningful elements with nationally colored social dogmas and the rules that actualize emotions, is restrained and suppressed.

Key words: the concept of emotions, the conceptual and linguistic pictures of the world, emotion-conceptosphere, cognitive-cultural phenomena, the concept of fear, structured knowledge about the emotional life of the person.

\section{Introduction}

With the change of millennia there has been a change in the scientific paradigm in psycholinguistics. The focus of atC Mykhalchuk Nataliia, Onufriieva Liana

DOI (article): https://doi.org/10.32626/2227-6246.2020-48.206-227 
tention of linguists is now fixed on the user of the language both as an individual who is a representative of a native culture and the language community to which he / she belongs. The linguistic imperative was the analysis of ethnically determined lexical and grammatical meanings, through which it is possible to identify the essential features of a particular linguistic culture and to get closer to understanding the mentality of the ethnic group - its carrier. Within this anthropocentric approach to the study of these psycholinguistic phenomena, our research deals with the study of the structure and semantics of lexemes for the designation of emotions in the English language.

Emotions belong to the semantic foundation of consciousness, organizing and directing it. The last explains the current increase in the interest of scientists in different industries according to emotions, their means of conceptualization and verbalization. As it was emphasized in different researches (Гончарук \& Онуфрієва, 2018; Mykhalchuk \& Bihunova, 2019), the knowledge of the world was realized through emotions. However, the lack of a comprehensive theory of emotions, the diversity and contradiction of their classifications, the heterogeneity of the processes of their definition complicate the study of verbalization of human emotional reactions.

The analysis of approaches to the study of emotions adopted in cognitive psychology and also in psycholinguistic testifies to the inextricable link between cognitions, emotions and a language as interdependent components of the emotional-cognitive system «consciousness - perception - conceptualization categorization" of emotions as the object of psycholinguistics.

One of the most relevant areas of modern cognitive linguistics is the study of concepts, including the concepts of emotions. The research of concepts of emotions is the undeveloped area in contemporary Psychology. Therefore, the purpose of this article is to define the role of the concept of emo-

(C) Mykhalchuk Nataliia, Onufriieva Liana DOI (article): https://doi.org/10.32626/2227-6246.2020-48.206-227 
tions in the conceptual and linguistic pictures of the world of Ukrainian and English people.

Achieving this goal we put the following tasks: 1) to analyze the definitions of emotion in Ukrainian and English languages; 2) to make a comparison of the definitions given in linguistic dictionaries; 3 ) establishing the role of concepts of emotions in the conceptual and linguistic pictures of the world of people of different ethnocultures.

\section{Methods of the research}

The following theoretical methods of the research were used to solve the tasks formulated in the article: a categorical method, structural and functional methods, the methods of the analysis, systematization, modeling, generalization.

\section{Results and the discussion}

The concept as a philosophical definition emerged in the time of scholastic Philosophy. In the nineteenth century, the term "concept» became actively used by literary critics who understood it as an «idea». Subsequently, the term was borrowed by linguists. However, in the researches of cognitive orientation it has different content. There are, for example, three approaches to interpreting the term «concept». Firstly, in the broadest sense the concepts include lexemes the meanings of which constitute the content of the national linguistic consciousness and form a «naive picture of the world» of native speakers. Secondly, in the narrower sense, concepts include semantic formations that, in one way or another one, characterize people of a particular ethnoculture and are marked by their linguocultural specificity. Finally, the concepts include only those semantic entities the list of which is largely limited and which are so called «key» for understanding the national mentality as specific one to the world of its people. The third approach is followed, for example, by A. Levitskyi, who understands the concept as the object from the «Ideal» world, (C) Mykhalchuk Nataliia, Onufriieva Liana

DOI (article): https://doi.org/10.32626/2227-6246.2020-48.206-227 
which has a name and reflects certain culturally conditioned perceptions of the Person about the "Reality» of the World (Левицький, 2004).

Concepts can denote both material entities and non-material ones, and the latter represent, to our mind, particularly reach material for linguistic researches, since conceptions of specific objects can largely be determined by their own knowledge of their denotation, in abstract concepts. These denotations are not a specific subject to direct material observation, and, consequently, perceptions of them are much more predetermined by the mentality of the speakers and thus may reveal more secrets about them.

A special place among these concepts of abstract entities takes the concept of emotions. Emotions shape a person's mental life, and emotional concepts are, in fact, the means by which we gain our experience and realize our feelings. It our research of emotional vocabulary that may seem particularly easy to understand the mentality of a particular ethnic group; moreover, unraveling the rules for the use of a word that denotes a metaphysical essence will bring us to the heart of the theory of emotions and bring us into the paradigm of the research, which includes the study of the physiology of emotions, the elegance that it unfortunately lacks of.

If we use the Ukrainian language, then we will find the following definitions of emotions: 1) emotion is a person's experience of his / her attitude to reality, to his / her personal and surrounding life; there are such word combinations as emotional experience, human feelings; 2) emotions (affect, emotional unrest) are called states such as fear, anger, sadness, joy, love, hope, sadness, pride, etc. Emotions are presented in certain psychological experiences, each is known in his / her own experience, and in bodily phenomena. Like feelings, emotions have a positive and a negative sensual tone associated with perceptions of satisfaction or dissatisfaction (Бондаренко, 2002). 
DOI: https://doi.org/10.32626/2227-6246.2020-48

In the English dictionaries we will find the following explanation for the word "emotion»: 1. Emotion is a strong human feeling such as love, hate, or anger. 2. Emotion is the complex psychophysiological experience of an individual's state of mind as interacting with biochemical (internal) and environmental (external) influences. In humans, emotion fundamentally involves «physiological arousal, expressive behaviors, and conscious experience». Emotion is associated with mood, temperament, personality and disposition, and motivation. Motivations direct and energize behavior, while emotions provide the affective component to motivation, positive or negative (Collins Cobuild English Language Dictionary, 1991: 266).

As we see, in Ukrainian and English languages emotions are called strong human feelings, and as examples there are feelings of fear, joy, hatred, anger and so on. In the lexical composition of the studied words denoting the emotions (for example, the emotion of joyness) are represented by the following lexical and grammatical classes of words:

- verbs of their own physical or mental activity: to rejoice, to have fun, to entertain, to enjoy, to please, to joy;

- nouns: names of feelings of joyness: joy, pleasure, fun, happiness, enjoyment, delight, pleasure;

- adjectives which characterize the emotions: joyful, cheerful, comforting, contented, shining, rainbow, happy, hungry, pleased, delighted, thrilled, overjoyed, satisfied, ecstatic, smug.

As we can see, the vocabulary for the designation of emotions is expressive and emotionally colored.

It should also be noted that scientists (Борисов, 2004; Левицький, 2004) underlined such a peculiarity of concepts of emotions, as a combination of universal and ethno-specific content. Although there is no answer in the humanities to the question of the relationship and the boundary between two components, it is no doubt that the physiological nature and psychological mechanisms of experiencing at least the basic (C) Mykhalchuk Nataliia, Onufriieva Liana

DOI (article): https://doi.org/10.32626/2227-6246.2020-48.206-227 
emotions are the same for all of humanity, and they are already overlaid with some historically conditioned emotional of a particular ethnic group. Confirmation can be found in our psychological research.

In contemporary English language world, the emotional concept of «fear» is one of the most commonly used by its self-identification. Fear is a universal base emotion that reflects the instinct of self-preservation and plays a leading role in providing human life.

We think that fear is one of the fundamental emotions that performs a protective function and is accompanied by certain changes in the activity of higher nervous system, such as: changes in pulse rate and respiration, blood pressure indicators, function of stomach. However, it should be noted that feelings of fear stimulate the ability to respond to adverse factors of objective reality. Being at the highest point of emotional excitement, one seeks ways to solve the problem, because fear specifically distorts reality, imprinting on the nature of its perception and interpretation. In the unfavorable situation, a person seeks to get rid of the state of helplessness and intimidation as soon as it is possible to minimize the effect of threatening factor. We can conclude that ideas about the emotion «fear» are localized in the negative associative-shaped zone of the linguistic picture of the world.

However, it should be noted that fear is a force that is capable of both destroying one's personality from inside, leaving him / her helpless in the circumstances, and mobilizing the internal forces of the person, thus helping to avoid the dangers and escape, as it is an extremely powerful motivational factor for modeling personal behavior. Fear can fairly be attributed to the leading factors that contributed to the development of civilization. It was the sense of real or perceived threat that encouraged humankind to unite in tribes, communities (the cities and states are subsequently formed of), because together it was much easier to withstand the attacks of beasts, other

(C) Mykhalchuk Nataliia, Onufriieva Liana DOI (article): https://doi.org/10.32626/2227-6246.2020-48.206-227 
DOI: https://doi.org/10.32626/2227-6246.2020-48 2020. ВипУСК 48 tribes, and even natural disasters. One of the foundations of religious beliefs is the fear of being punished by higher powers or of suffering after death, which in many religions is the boundary between earthly existence and eternal life in heaven. This thesis makes it possible to consider the emotion under study as a factor in motivating the morality of contemporary man's behavior.

The concept is a complex multilayer formation, the central part of which is the core. The core of the emotional-conceptual sphere is the mental representations of knowledge of the person about their own emotions as the facts of manifestation of the activity of the human emotional sphere. Its peripheral zone also includes information about all spheres of human existence that in one way or another predetermine its functioning or are interpreted through the prism of its existence. This fact testifies to the imposition of the emotional conceptual sphere on other parts of the conceptual picture of the world of the person, and, consequently, on its determinant role in the consciousness of the individual: all concepts are «emotional» from the point of view that nothing can be comprehended (proxified and categorized) without direct or indirect intervention in the cognition of the emotional sphere of consciousness. So, emotions are the foundation that seems to "cling" to the conceptual picture of the world of representatives of any linguistic community.

The emotional conceptosphere is a dynamic labile semiotic system, a historical and social formation, the development of which is conditioned by both extralinguistic and actual linguistic factors. Psycholinguistic factors that determine the development of the emotion-conceptual sphere in the diachrony of culture are asymmetry of the linguistic sign, expansion of registers of human communication, social, stylistic differentiation of the language. The main extralinguistic factors that determine the formation and transformation of the emotional and conceptual sphere are the complications of human practi(C) Mykhalchuk Nataliia, Onufriieva Liana

DOI (article): https://doi.org/10.32626/2227-6246.2020-48.206-227 
cal activity, the emergence of theoretical knowledge as a way of mastering the person in the world, socialization of personality, moral orientation of social institutions, etc.

The vast majority of the emotion-concept sphere is a verbalized paradigm. It is characteristically formulated by quite diverse languages, mainly secondary nominations, such as metaphor and metonymy: all abstract concepts, including emotional ones, are metaphorical in nature. The widespread use of the means of secondary characterization of emotions is due to a high prevalence and productivity of such types of nomination in the language at its present stage of development due to, on the one hand, the poverty of direct designations of a human mental world, and, on the other, the archetypes of human cognitions.

Indirect nominations of emotions are the process and the result of reassessment of already existing psycholinguistic realities. The contemporary notation of emotions is based on the transfer of the names of real fragments of the world (physiological reactions of a human body, its physical actions, phenomena of nature, mythological images, etc.) to the mental activity of the person.

Organizationally emotion-concept sphere is a set of hierarchically ordered paradigm, verbalized using lexical and phraseological means of emotional concepts, which are "quanta», such as structured knowledge about the emotional life of the person, which are for each other in a complex of structuralsemantic and functional relationships. Therefore, for the research of the nature of the emotional-conceptual sphere, it is extremely important to understand the essence of the emotional concept, to describe and reflect their components, to analyze the linguistic means by which they are represented. Such a description needs to take into account the existing in the socio-cultural life of the community of psychological, sociological and semiotic factors, which together form a cultural factor

(C) Mykhalchuk Nataliia, Onufriieva Liana DOI (article): https://doi.org/10.32626/2227-6246.2020-48.206-227 
DOI: https://doi.org/10.32626/2227-6246.2020-48 2020. ВипУСК 48

that determines the formation and functioning of concepts as a cognitive-cultural phenomena.

One of the main concepts in the structure of the emotion-concept sphere is the emotional concept of fear, which accumulates knowledge about the underlying emotion, human existence is not possible without. The emotion of fear is one of the most important components of the emotional conceptual sphere of a man, which determines the process of knowledge and orientation of this man in the world, characterized by biological, psychological and socio-cultural dimensions. Fear is a fundamental feature of a human being, a natural universal basic emotion that reflects the instinct of self-preservation and plays a leading role in the maintenance of human life. Functional purpose of fear is that it is manifested in the form of affectively heightened perception of threat to life, well-being or the person and active or passive reactions to adverse environmental factors. The view of the world through the prism of danger leads to a specific distortion of the reality, which directly affects the nature of its perception of the individual, the correct interpretation of events, the successful choice of ways to overcome difficulties and the realization of unpleasant and harmful to the body of emotions in general. In addition to the prototype "perspective» reaction of fear is the action of threatening a future event, it can appear as a "retrospective» emotion that arises in the case of mental reproduction of the past danger having been experienced.

Therefore, the primary cause of fear is the physical or mental perception of a certain state of affairs, which is categorized by consciousness as a dangerous situation that does not meet the person's need for a sense of security. This assessment is due to the fact that there is a mismatch between the content component of the setting and the image of a real situation - it is a situation of cognitive dissonance, which is experienced as a state of discomfort. The latter inevitably leads to the search for opportunities to return a sense of security and peace.

(C) Mykhalchuk Nataliia, Onufriieva Liana

DOI (article): https://doi.org/10.32626/2227-6246.2020-48.206-227 
The state of fear is directly presented in the involuntary neurophysiological and neuromotor responses of the person. This includes, for example, symptoms such as inability to concentrate, decreased muscle tone, increased heart rate, which reflects anxiety, discomfort, changes in facial expressions and pantomimes, involuntary speech cries and so on. These symptoms are the basis for classifying the emotion as unpleasant, in the most cases disorganizing the activity of the individual, and, accordingly, rated it as a negative one.

After the initial intuitive assessment, a more conscious intellectual assessment of both the danger itself and its psychophysiological and physical state is bound to emerge. Assessment entails the emergence of a meaningful desire to end the adverse effect through a deeper analysis of possible ways out and developing a plan of actions; will lead to the desired result. The emotion and the assessment contribute to the formation of intentions, explicating the beginning and the end of the volitional act.

At the exit of the situation, the subject's conscious or controlled actions and linguistic reactions to the fear-causing factor are: adaptation to environmental conditions or struggle, or, conversely, complete subordination to this emotional experience with the following negative or positive consequences for the person. In this case, people tend to focus on their knowledge and experience.

The specificity of the person's reaction to the threat and the occurrence of the emotion of fear is conditioned by the level of his / her socialization within a particular ethnic group. Fear is a basic emotion that, having a biological dimension, is socially constructed and acquires appropriate cultural characteristics. It is a question of imposing social restrictions on the ways of emotional expressions, conscious and involuntary actions of the person, with the aim to find a way out of the created situation, among which the most prominent is the expression of fear response by the units (or patterns) of the na- 
DOI: https://doi.org/10.32626/2227-6246.2020-48 2020. випУСК 48

tional language. In this case, social determination explains the origin of emotion, cultural-historical determination which predicts the forms of its expression and modes of regulation, and this knowledge is included directly into the structure of the emotional concept. The gained experience is structured in the mind of the person in the form of a prototypical lingual-psychological model of emotion of fear, which is described by a fixed set of events: 1) a dangerous situation; 2) the emotion of fear and spontaneous reactions of the person; 3 ) in some a way conscious actions and linguistic reactions of the person. This model generalizes the knowledge that forms the information core of the emotional concept of fear and is represented by multilevel linguistic and communicative means. Therefore, the analysis of the latter allows us to penetrate the structure of the concept under study, to identify significant and additional fragments of its semantic content.

The study of the emotional vocabulary, just as the multivariate analysis of emotional speech indicates that various fragments of the emotional sphere of human being are reflected and understood in the paradigm of emotional concepts. Representations in the language of a particular ethnic group undergo a concentration in the relevant emotional concepts, knowledge of emotions that are socialized in a particular culture. Considering the multidimensionality of the phenomenon of emotions and, accordingly, the informative saturation of knowledge about it, which is accumulated and structured by a concept, a verbalized emotional concept can be defined as a complex dynamic structural-semantic construct of human consciousness, the specificity of which is determined by the unity of the ethnocultural and social characteristics.

The breadth of volume and heterogeneity of the semantics of emotional concepts raises questions about the identification and modeling of linguae conceptual architectonics of these concepts. The solution of this problem is connected with the number of difficulties, being conditioned by the abstractness of the C Mykhalchuk Nataliia, Onufriieva Liana

DOI (article): https://doi.org/10.32626/2227-6246.2020-48.206-227 
sphere of emotions, which they conceptualize. The abstraction of the concept of emotion leads to a constant search for the individual and collective consciousness of ways of expressing a mood emotionally, which determines the motility of the corresponding fragment of the linguistic picture of the world, the mosaic of motivation of the nominees of emotions, the wide involvement of the means of their indirect designation.

Analyzing the informational structure of the emotional concept of fear provides some basic grounds for sampling individual parts of the concept according to a series of events. The emotional concept is a concept that represents a situation in which a subject experiences a particular emotional state. A reference situation is defined as a localized fragment of the surrounding reality in the human (personal or public) sphere, which embodies a certain spatial-temporal juxtaposition of objects capable of being perceived simultaneously by the person. Categorized situations are characterized by stereotyping, reflecting socially significant interpretation of information. The simplest elements of the situation are events, which include natural factors, as well as acts of human behavior (actions, concessions, states, changes, etc.). They are recorded by human consciousness as a result of knowledge of the world in order to express these elements by means of the language.

At the conceptual level of consciousness, emotion is represented as a link of the unfolded cause and effect chain, which includes three events: 1) the event that caused the emotion; 2) person's emotion; 3) the reaction. To describe these three fundamental moments of the situation of the emergence and the experience of the individual emotions of fear, the most successful is the involvement of the frame structure, because frame creates a logically complete schematized picture in the process of knowing the stereotypical situation, fixing on its structure, on the characteristic features of a number of different situations, dedicated some field of knowledge. The frame implicates a complex situation; it can be correlated with a 
DOI: https://doi.org/10.32626/2227-6246.2020-48

frame that contains everything that is typical and essential for a given set of circumstances. In our case, it is worth noting that A. Borisov remarked that lexical units denoting emotions can be captured by single frames (Борисов, 2004: 108).

The analysis of definitions of fear allowed us to distinguish the following main core features of the emotional concept of fear in the English language: fear is an unpleasant, painful emotion or feeling caused by the nearness or the possibility of impending danger to oneself or others who are important accompanied by a desire to avoid or to escape it.

In the semantics of the analyzed token, there is a generic semantic «emotion» or «feeling» (emotion or feeling) that points to the corresponding denotative sphere of human consciousness, represented by the superordinate (the highest level of generalization) category of emotion. All other species of this lexical unit serve to specify the meaning of tokens. Among the species the main components are the following: the lexical unit "painful» that interacts with the semantic meaning "negative» (unpleasant), "danger / threat», "desire to avoid or to escape it - the desire to avoid or avoid the threat», "the nature of the impending danger - inevitable: real / close»; "the possibility of impending danger - possible / inevitable», "oneself or somebody who is important - the individual / people close to him».

The internal form of the emotional concept of fear, which manifests itself as a result of etymological analysis of its keyword, has undergone significant changes according to this lexicographic data. The etymological basis of the concept of fear is the German root *fer, which means «небезпека, шкода», for example fer: sudden calamity, danger "раптове лихо, небезпе$\kappa а$; власне страх», which corresponds to far: ambush «nacm-

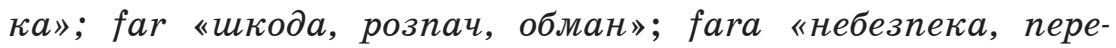
ляк», far «зло, икода, нещастя». Comparison of the current definition of fear and its ancient correspondences show that earlier in the basic zone of the emotional concept of fear was localized information about the danger that would be the cause (C) Mykhalchuk Nataliia, Onufriieva Liana

DOI (article): https://doi.org/10.32626/2227-6246.2020-48.206-227 
of fear, while now the basic was knowledge about the actual signs of the emotional state of the person.

\section{Conclusions}

Consequently, in contemporary English categorically different aspects of lexical unit of fear are fixed by derivative word-building units, which explicate: the state of the person; features of the character of the person; negative evaluation of the object of the threat; manner of the behavior.

The frame of the emotional concept of fear, which contains data of a declarative nature, reflects the constant and unchanging features of the situation of the occurrence of fear: the appearance of threat causes the appearance of fear, which is presented in the physiological and behavioral reactions of a man.

The analysis of the research on the structure of the emotional concept of fear makes it possible to state that each of the allocated blocks of reference contains knowledge of different qualities, relating to both the nucleus and the periphery.

Summarizing all the information, we consider the emotional concept of fear as a complex nuclear-peripheral configuration of knowledge about prototypical and not prototypical concepts, figurative and value attributes of the emergence, experience and elimination of emotion of fear. This configuration forms the conceptual basis on which the core of the meaning of the multilevel units of the given emotional concept in contemporary English is constructed. It is also participated in the formation of mental spaces that are constructed during the perception of fragments of English-language texts that describe the situation of the hero's experience of the state of fear. If the informative structure of the emotional concept is «responsible» for the denotative aspect of the meaning of its nominees, then their connotative aspect captures the concept's place in the English conceptual picture of the world. The status of the emotional concept of fear in it is conditioned by the attitude of the ethnos to the correlative emotion. The point is

(C) Mykhalchuk Nataliia, Onufriieva Liana DOI (article): https://doi.org/10.32626/2227-6246.2020-48.206-227 
that, having a biological basis, fear receives a socialized, nationally and culturally conditioned form of the expression that is entirely based on a nationally specific, evaluative attitude of the person to emotions as a socialized phenomenon. Being the basis of the emotional concept of fear, this emotion projects the peculiarities of his / her experience on his / her semantic structure. In such a way the socialization of fear, which is largely normatively determined, predicts the status of the emotional concept under study as being essentially axiological, demonstrating the connection of its meaningful elements with nationally colored social dogmas and the rules that actualize emotions, is restrained and suppressed.

\section{Literature}

Бондаренко Я. О. Ключові концепти у мовленні акцентуйованих мовних особистостей (на матеріалі сучасної американської художньої прози). Проблеми семантики слова, речення та тексту. Київ : КНЛУ, 2002. Вип. 8. С. 33-38.

Борисов А. А. Реализация концепта «FEAR» паремиологическими средствами современного английского языка. Языковые категории: границы и свойства: Мат-лы докл. междунар. науч. конф. (Минск, 22-23 марта 2004 г.). Минск : МГЛУ, 2004. Ч. 2. С. 108-111.

Гончарук Н., Онуфрієва Л. Психологічний аналіз рівнів побудови комунікативних дій. Psycholinguistics. Психолінгвістика. Психолингвистика. 2018. Вип. 24 (1). С. 97-117. DOI 10.31470/2309-17972018-24-1-97-117.

Левицький А. Е. Основи функціональної лінгвістики. Ніжин : Редакційно-видавничий відділ НДПУ, 2004. $124 \mathrm{c.}$

Collins Cobuild English Language Dictionary (1991). J. Sinclair (Ed.). London : Harper Collins Publishers. 1703 p.

Mykhalchuk, N., \& Bihunova, S. (2019). The verbalization of the concept of «fear" in English and Ukrainian phraseological units. Cognitive Studies. Études cognitives. № 19. Warsaw. Poland. URL : https:// doi.org/10.11649/cs.2043.

\section{References}

Bondarenko, Ya. O. (2002). Kliuchovi kontsepty u movlenni aktsentuiovanykh movnykh osobystostei (na materiali suchasnoi amerykanskoi

C Mykhalchuk Nataliia, Onufriieva Liana

DOI (article): https://doi.org/10.32626/2227-6246.2020-48.206-227 
khudozhnoi prozy) [Key concepts in a speech of accentuated linguistic people (based on contemporary American prose)]. Problemy semantyky slova, rechennia ta tekstu - Problems of semantics of word, sentence and text, 8, 33-38. Kyiv : KNLU [in Ukrainian].

Borisov, A. A. (2004). Realizatsiia kontsepta «FEAR» paremiologicheskimi sredstvami sovremennogo angliiskogo yazyka [Implementation of the concept of «FEAR» by paremiological means of contemporary English]. Yazykovyie kategorii: granitsy i svoistva - Language categories: boundaries and qualities: Proceedings of Int. scientific conf. (Minsk, March 22-23, 2004), 2, 108-111. Minsk : MGLU [in Russian].

Honcharuck, N., \& Onufriieva, L. (2018). Psykholohichnyi analiz rivniv pobudovy komunikatyvnykh dii [Psychological analysis of levels of communicative actions' constructing]. Psykholinhvistyka. Psikholingvistika. Psycholinguistics - Psycholinguistics. Psycholinguistics. Psycholinguistics, 24 (1), 97-117. DOI 10.31470/2309-1797-201824-1-97-117 [in Ukrainian].

Levytskyi, A. E. (2004). Osnovy funktsionalnoi linhvistyky [Fundamentals of Functional Linguistics]. Nizhyn : Redaktsiino-vydavnychyi viddil NDPU [in Ukrainian].

Collins Cobuild English Language Dictionary (1991). J. Sinclair (Ed.). London : Harper Collins Publishers.

Mykhalchuk, N., \& Bihunova, S. (2019). The verbalization of the concept of «fear» in English and Ukrainian phraseological units. Cognitive Studies. Études cognitive, (Vol. 19). Warsaw. Poland. Retrieved from https://doi.org/10.11649/cs.2043.

Михальчук Наталія, Онуфрієва Ліана. Психолінгвістичні особливості репрезентації емоцій за допомогою концепту «страх»

\section{АНОТАЦІЯ}

Мета cmammi - визначити роль емоцій у концептуальній і лінгвістичній картинах світу українського й англійського населення.

Для розв'язання поставлених у роботі завдань використано такі теоретичні методи дослідження: категоріальний, структурно-функціональний, аналіз, систематизація, моделювання, узагальнення.

Результати дослідження. Доведено, що страх є однією з фундаментальних емоцій, що виконує захисну функцію та супроводжується певними змінами діяльності вищої нервової системи, а саме: зміною частоти

(C) Mykhalchuk Nataliia, Onufriieva Liana DOI (article): https://doi.org/10.32626/2227-6246.2020-48.206-227 
пульсу і дихання, показників артеріального тиску, роботи шлунку. Однак слід зауважити, що почуття страху стимулює здатність реагувати на несприятливі чинники об'єктивної дійсності. Перебуваючи у найвищій точці емоційного збудження, людина шукає шляхи розв'язання проблеми, оскільки страх специфічно викривляє дійсність, накладаючи відбиток на характер її сприйняття й інтерпретації. У несприятливій ситуації людина прагне якнайшвидше позбавитися від стану безпорадності, наляканості, мінімізувати дію загрозливого чинника. Ми можемо зробити висновок, що уявлення щодо емочії «страх» локалізуються у негативній асоціативно-образній зоні мовної картини світу.

Показано, що організаційно емочіо-концептосрера являє собою сукупність ієрархічно упорядкованої парадигми, вербалізованої за допомогою лексичних і фразеологічних засобів емочійних концептів - «квантів» - структурованого знання щодо емоційного життя індивіда, які знаходяться один з одним у складних структурно-семантичних і функціональних відношеннях. Тому для дослідження природи емоціо-концептосрери надзвичайно важливо зрозуміти сутність емочійного концепту, описати і відобразити його складові, проаналізувати ті мовні засоби, якими вони репрезентуються. Обгрунтовано, що такий опис потребує врахування існуючих у соціокультурному житті спільноти психологічних, сочіологічних і семіотичних факторів, що у сукупності утворюють загальнокультурний чинник, який детермінує формування та функціонування концептів як когнітивно-культурних явищ.

Висновок. Отже, у сучасній англійській мові категоріально різні аспекти одиниці fеar фіксуються похідними словотвірними одиницями, які експлікують: стан індивіда; риси характеру індивіда; негативну оцінність об'єкта загрози; манеру поведінки тощо.

Фрейм емоційного концепту "страх», який містить дані декларативного характеру, відображає постійні та незмінні риси ситуації виникнення страху: поява загрози зумовлює виникнення страху, що виявляється у фізіологічних і поведінкових реакціях людини.

Підсумовуючи зазначене вище, ми розглядаємо емоційний концепт "страх» як складну ядерно-перифрерійну конфрігурацію знань про прототипові й непрототипові поняттєві, образні та ціннісні ознаки виникнення, переживання й усунення емоції страху. Зазначена конфігурація складає концептуальне підгрунтя, на якому вибудовується ядро значення різнорівневих одиниць-репрезентатів окресленого емоційного концепту (C) Mykhalchuk Nataliia, Onufriieva Liana

DOI (article): https://doi.org/10.32626/2227-6246.2020-48.206-227 http://journals.uran.ua/index.php/2227-6246 
в сучасній англійській мові. Вона ж бере участь у формуванні ментальних просторів, які конструюються під час сприйняття фрагментів англомовних текстів, що описують ситуацію переживання героєм стану страху. Якщо інформативна структура емоційного концепту «відповідає» за денотативний аспект значення його номінантів, то їх конотативний аспект фріксує місце концепту в англійській концептуальній картині світу. Статус у ній емоційного концепту "страх» зумовлюються ставленням етносу до корелюючої емоції. Йдеться про те, що, маючи біологічне підгрунтя, страх отримує соціалізовану, національно-культурно обумовлену форму прояву, яка цілком базується на національно специфічному, оцінному ставленні людини до емоцій як соціалізованого феномену. Будучи основою емоційного концепту "страх", зазначена емоція проектує особливості свого переживання на його семантичну структуру. Зокрема, соціалізованість страху, прояви якого є значною мірою нормативно детермінованими, зумовлює статус досліджуваного емоційного концепту як сутності глибоко аксіологічної, такої, що демонструє зв'язаність своїх значеннєвих елементів із начіонально забарвленими соціальними догмами та правилами, котрими емоція "страх» засуджується, а отже, повинна бути стримана і придушена.

Ключові слова: концепт "емоції», концептуальна та лінгвістична картини світу, емоційна концептосрера, когнітивно-культурні явища, концепт «страх», структуровані знання щодо емоційного життя людини.

Михальчук Наталия, Онуфриева Лиана. Психолингвистические особенности репрезентации эмоций с помощью концепта "страх»

\section{АННОТАЦИЯ}

Цель статьи - определить роль эмоций в концептуальной и лингвистической картинах мира украинского и английского населения.

Для решения поставленных в работе задач использованы следующие теоретические методы исследования: категориальный, структурно-функциональный анализ, систематизация, моделирование, обобщение.

Результаты исследования. Доказано, что страх является одной из фундаментальных эмоций, которая выполняет защитную функцию и сопровождается определенными изменениями деятельности высшей нервной системы, а именно: изменением частоты пульса и дыхания, по-

(C) Mykhalchuk Nataliia, Onufriieva Liana DOI (article): https://doi.org/10.32626/2227-6246.2020-48.206-227 
DOI: https://doi.org/10.32626/2227-6246.2020-48 2020. випУСК 48

казателей артериального давления, работы желудка. Однако следует заметить, что чувство страха стимулирует способность реагировать на неблагоприятные факторы объективной действительности. Находясь в самой высокой точке эмочионального возбуждения, человек ищет пути решения проблемы, поскольку страх специфически искажает действительность, накладывая отпечаток на характер ее восприятия и интерпретации. В неблагоприятной ситуации человек стремится как можно быстрее избавиться от состояния беспомощности, испуганности, делает попытки минимизировать воздействие угрожающего фактора. Мы можем сделать вывод, что представления об эмоции "страх» локализуются в отрицательной ассоциативно-образной зоне языковой картины мира.

Показано, что организационно эмоцио-концептосфера представляет собой совокупность иерархически упорядоченной парадигмы, вербализированной с помощью лексических и фразеологических средств эмоциональных концептов - или "квантов» - структурированного знания об эмоциональной жизни индивида, которые находятся друг с другом в сложных структурно-семантических и функциональных отношениях. Поэтому для исследования природы эмоцио-концептосферы чрезвычайно важно понять сущность эмоционального концепта, описать и отобразить его составляющие, проанализировать те языковые средства, которыми они эксплицируются. Обосновано, что такое описание требует учета существующих в сочиокультурной жизни сообщества психологических, сочиологических и семиотических факторов, которые в совокупности образуют общекультурный фактор, который, в свою очередь, детерминирует формирование и функционирование концептов как когнитивно-культурных явлений.

Вывод. Показано, что в современном английском языке категориально различные аспекты единицы fеar фиксируются производными словообразовательными единицами, которые эксплицируют: состояние индивида; черты характера индивида; негативную оценочность объекта угрозы; манеру поведения и т. п.

Фрейм эмоционального концепта "страх», содержащий данные декларативного характера, отражает постоянные и неизменные черты ситуации возникновения страха: появление угрозы обусловливает возникновение страха, который проявляется в физиологических и поведенческих реакциях человека.

(C) Mykhalchuk Nataliia, Onufriieva Liana

DOI (article): https://doi.org/10.32626/2227-6246.2020-48.206-227 http://journals.uran.ua/index.php/2227-6246 
DOI: https://doi.org/10.32626/2227-6246.2020-48 2020. випуск 48

Обосновано, что мы рассматриваем эмоциональный концепт "страх» как сложную ядерно-периферийную конфигурацию знаний о первичных и вторичных понятийных, образных и ченностных признаках возникновения, переживания и устранения эмоции "страх». Указанная конфигурация составляет концептуальное основание, на котором выстраивается ядро значения разноуровневых единиц-репрезентантов указанного эмоционального концепта в современном английском языке. Эти единицы участвуют в формировании ментальных пространств, которые конструируются при восприятии фрагментов англоязычных текстов, описывающих ситуацию переживания героем состояния страха. Если информативная структура эмоционального концепта совпадает с денотативным аспектом значения его номинантов, то их конотативный аспект фиксирует место данного концепта в английской концептуальной картине мира. Статус в ней эмоционального концепта "страх» обусловлен отношением этноса к коррелирующим эмоциям. Речь идет о том, что, имея биологическое основание, страх получает социализированную, национально и культурно обусловленную форму проявления, полностью базируется на национально специфическом, оценочном отношении человека к эмоциям как социализированному феномену. Являясь основой эмоционального концепта «страх», указанная эмоция проектирует особенности своего переживания на его семантическую структуру. В частности, социализированность страха, проявления которого в значительной степени являются нормативно детерминированными, обусловливает статус исследуемого эмоционального концепта как сущности глубоко аксиологической, такой, которая демонстрирует связанность своих смысловых элементов с национально окрашенными социальными догмами и правилами, которыми эмоция «страх» осуждается, $a$, следовательно, должна быть сдержана и подавлена.

Ключевые слова: концепт "эмоции», концептуальная и лингвистическая картины мира, эмоциональная концептосфера, когнитивно-культурные явления, концепт "страх», структурированные знания об эмоциональной жизни человека.

Original manuscript received February 09, 2020 Revised manuscript accepted March 04, 2020

(C) Mykhalchuk Nataliia, Onufriieva Liana DOI (article): https://doi.org/10.32626/2227-6246.2020-48.206-227 